\title{
OUTBREAKS ASSOCIATED TO BLOODSTREAM INFECTIONS WITH STAPHYLOCOCCUS AUREUS AND COAGULASE-NEGATIVE STAPHYLOCOCCUS SPP IN PREMATURE NEONATES IN A UNIVERSITY HOSPITAL FROM BRAZIL
}

\section{Denise Von Dolinger de Brito ${ }^{1 *}$; Elias Jose Oliveira ${ }^{1}$; Ana Lúcia da Costa Darini²; Vânia Olivetti Steffen Abdallah ${ }^{3}$; Paulo P. Gontijo Filho ${ }^{1}$}

${ }^{1}$ Área de Imunologia, Microbiologia e Parasitologia, Laboratório de Microbiologia, Universidade Federal de Uberlândia, Uberlândia, MG, Brasil; ${ }^{2}$ Laboratório Especial de Bacteriologia e Epidemiologia Molecular, Faculdade de Ciências Farmacêuticas de Ribeirão Preto, Universidade de São Paulo, Ribeirão Preto, SP, Brasil; ${ }^{3}$ Berçário de Alto Risco, Hospital de Clínicas, Universidade Federal de Uberlândia, Uberlândia, MG, Brasil

Submitted: December 02, 2004; Returned to authors for corrections: April 05, 2005; Approved: February 26, 2006

\begin{abstract}
Staphylococcus aureus and coagulase-negative staphylococci (CoNS) are among the most important nosocomial pathogens in patients from neonatal intensive care units, mainly in bloodstream infections. The main objective of this study is to determine the occurrence of nosocomial infections by these microorganisms using two surveillance systems (Laboratorial Surveillance and National Nosocomial Infection Surveillance System) and to determine the most important risk factors during a two-year period (2001-2002). Two outbreaks by both methicillin susceptible S. aureus (MSSA) (1.5\%) and methicillin resistant CoNS (MRCoNS) (1.0\%) were observed, from January to February/02 and August to September/02. Endemic incidence rates of 3.77\% and $5.16 \%$ of S. aureus and CoNS, respectively were detected. Risk factors included age $\leq 7$ days, hospitalization $\geq 7$ days and utilization of polietilene central vascular catheter (CVC) through vein dissection (phlebotomy), but none of these independent factors were confirmed by the multivariate analysis. However, oxacillin resistant CoNS prevailed (66.0\%) in the epidemic episodes. Molecular analysis by pulsed field gel electrophoresis showed the polyclonal nature of $S$. aureus isolates. In conclusion, two outbreaks were identified of mixed etiology by MSSA and MRCoNS associated to the lack of an adequate material (central venous catheter) for neonates, related invasive procedure. The outbreaks were controlled with the substitution of polietilene CVC for peripherally inserted central catheter.
\end{abstract}

Key words: polymicrobial, polyclonal, outbreaks, neonates, staphylococci

\section{INTRODUCTION}

Among the agents of infectious diseases in neonates are emphasized Staphylococcus aureus and coagulase-negative staphylococci (CoNS) as being predominantly of endemic nature (10). Besides, they are the main cause of sepsis in Neonatal Intensive Care Unit (NICU) (23), and have implied in outbreaks, often with significant increase in morbidity, mortality, length of stay and cost (11). Outbreaks attributed to S. aureus usually by methicillin-resistant Staphylococcus aureus (MRSA) phenotype can eventually occur (2) and generally, most infections are thought to be monoclonal (9).

The occurrence of outbreaks caused by multiple clones or species have been reported in a few cases mainly in NICU (21). However, reports of polymicrobial and polyclonal outbreaks are increasing $(7,25)$ due to staphylococci and Gram negative bacilli $(14,29)$.

Because of economic restrictions, health care is not a priority in most developing countries. One important issue is the shortage of disposable items designed for invasive procedures (30).

*Corresponding Author. Mailing address: Av. Floriano Peixoto, 5322, Bloco 09, Apto. 302, Residencial Buritis, B. Umuarama. 38405-184, Uberlândia, MG, Brasil. Tel.: (+5534) 3232-2280, Fax: (+5534) 3218-2333. E-mail: denisebrito@ terra.com.br 
The objective of this study was to investigate two outbreaks associated to methicillin susceptible Staphylococcus aureus (MSSA) and CoNS through a case control study in neonates interned in a NICU at Hospital Federal of Uberlândia, Minas Gerais, Brazil, in the period from January/2001 to December/2002.

\section{MATERIALS AND METHODS}

\section{Institution}

The NICU of Uberlândia Federal University Hospital comprises ten beds and annually approximately 500 admissions are realized.

\section{Definitions}

Polyclonal infection is originated by more than one clone and polymicrobial infection is that caused by more than one microorganism (21).

\section{Design of the study}

The epidemiologic surveillance for evaluation of nosocomial infection occurrence in the NICU was performed according to the National Nosocomial Infection Surveillance System (NNISS) with daily visits to the unit to search the nosocomial infections and the following risk factors: central venous catheter, peripheral venous catheter, respirator and weigh $\leq 1000 \mathrm{~g}$, and through daily visits to hospital laboratory to obtain staphylococci cultures isolated from infections in neonates hospitalized in the period of 2001-2002. The two outbreaks were defined by statistical analysis $(\mathrm{p} \leq 0.05)$, when compared with the endemic period. It was used case-control study where the cases represented 20 neonates with clinic and microbiologic diagnostic of staphylococcal infection and the control neonates hospitalized in the same period without diagnostic of disease or infection.

\section{Microbiological studies}

Blood culture bottles were plated on trypticase soy agar with $5 \%$ sheep blood, and the results were incubated for $24 \mathrm{~h}$ at $35^{\circ} \mathrm{C}$. Staphylococcus isolates were identified as $S$. aureus by the manitol fermentation, DNAse and coagulase activity and for CoNS were performed Gram stain and detection or not of enzyme production (coagulase and catalase). The antimicrobials sensitivity of the Staphylococcus isolates in the epidemic period was determinated by the disk diffusion method using the following disks (OXOID LTD., Basingstoke, Hampshire, England): ampicillin, oxacillin, gentamicin, ciprofloxacin, sulfazotrin, clindamicin, tetracycline, cloranfenicol, rifampicin, vancomycin, imipenem and ampicillin/ sulbactam and by the dilution method using the oxacillin (OXOID LTD., Basingstoke, Hampshire, England) concentrations of $0.25 \mu \mathrm{g} / \mathrm{mL}$ to $1024 \mu \mathrm{g} / \mathrm{mL}$ and interpreted according to the National Committee for Clinical Laboratory Standards $(16,17)$.

The genotypic analysis of methicillin susceptible Staphylococcus aureus (MSSA) was performed based on pulsed-field gel electrophoresis (PFGE) according to Loureiro et al., 2000 (12). The fragments of DNA were generated by digestion with restriction enzyme SmaI using the Gene Navigator apparatus (Pharmacia Biotech). The electrophoretic profiles of molecular typing were analyzed visually comparing the DNA fragments of each studied strain considering the number and dimensions of fragments. The criteria to definition of genetic profiles were defined by Tenover et al., 1995 (24).

\section{Statistical analysis}

The analysis of risk factors for infection were performed using the $\chi^{2}$ - test and Fisher's exact. The risk factors that showed significance $(\mathrm{p} \leq 0.05)$ in the univariated analysis were revaluated using a logistic regression model (multivariate analysis) through the statistical package SPSS (Version 10).

\section{RESULTS}

The rate of incidence of nosocomial infection gauged by the NNIS system was $27.5 \%$ (219/795) and considering only staphylococci infection the frequency was $8.9 \%$ (71/795). In concerning the distributions of $S$. aureus and CoNS endemic and epidemic infection, the most common locations were bloodstream and eyes, as many as endemic or epidemic (Table 1).

Two outbreaks of mixed etiology by MSSA and methicillinresistant coagulase-negative staphylococci (MRCoNS) were detected, through surveillance performed by microbiology laboratory, corresponding respectively to the periods of January-February/02 and august-september/02 (Fig. 1), defined by statistical criterions ( $\mathrm{p} \leq 0.05$ ), when compared with endemic rates.

The epidemiological investigation of two outbreaks was performed using case-control study (Tables 2 and 3). The predisposing factors of infection corresponding to the two outbreaks of staphylococci were: age $\leq 7$ days, hospitalization $\geq 7$ days and utilization of polietilene $\mathrm{CVC}$ through dissection of vein (phlebotomy). There was not independent risk factor by multivariate analysis. The first outbreak (Jan/Feb 02) was resolved in March/02 by continuous utilization of peripherally insertion central catheter (PICC), but because of the suspension of this use in August/02, the emerging of the second outbreak by staphylococcal was verified.

While the CoNS isolates showed multirresistance, S. aureus isolates showed resistance rates $(\cong 40.0 \%)$ only to rifampicin, sulfazotrin and gentamicin. The oxacillin minimal inhibitory concentration (MIC) 90 $_{90}$ concerning CoNS and S. aureus isolates was $256 \mu \mathrm{g} / \mathrm{mL}$ and $0.25 \mu \mathrm{g} / \mathrm{mL}$ respectivelly.

SmaI digestion of bacterial DNA to PFGE was performed on 18 MSSA isolates, including six of endemic and 12 of epidemic period. The predominance of polyclonal profile was observed. However, one cluster (isolates number 23, 24 and 30) into the epidemic period (Fig. 2) was detected. 
Table 1. Staphylococci infection of endemic and epidemic nature in the Neonatal Intensive Care Unit (NICU) of Uberlândia Federal University Hospital during the period from 2001 to 2002.

\begin{tabular}{|c|c|c|c|c|c|c|}
\hline \multirow[t]{2}{*}{ Infection } & \multicolumn{2}{|c|}{ S. aureus } & \multirow[b]{2}{*}{$\begin{array}{c}\text { Total } \\
\mathrm{N}=30(\%)\end{array}$} & \multicolumn{2}{|c|}{ CoNS } & \multirow[b]{2}{*}{$\begin{array}{c}\text { Total } \\
\mathrm{N}=41(\%)\end{array}$} \\
\hline & $\begin{array}{l}\text { Epidemic } \\
\mathrm{N}=12(\%)\end{array}$ & $\begin{array}{c}\text { Endemic } \\
\mathrm{N}=18(\%)\end{array}$ & & $\begin{array}{c}\text { Epidemic } \\
\mathrm{N}=8(\%)\end{array}$ & $\begin{array}{c}\text { Endemic } \\
\mathrm{N}=33(\%)\end{array}$ & \\
\hline Sepsis & $8(66.7)$ & $12(66.7)$ & $20(66.7)$ & $7(87.5)$ & $22(66.7)$ & $29(70.7)$ \\
\hline Conjunctivitis & $3(25.0)$ & $4(22.3)$ & $7(23.3)$ & $1(12.5)$ & $10(30.3)$ & $11(26.8)$ \\
\hline Pneumonia & - & $1(5.5)$ & $1(3.3)$ & - & - & - \\
\hline Otitis & - & & - & - & $1(3.0)$ & $1(2.5)$ \\
\hline Rinitis & $1(8.3)$ & $1(5.5)$ & $2(6.7)$ & - & - & - \\
\hline
\end{tabular}

CoNS = coagulase-negative Staphylococci

Table 2. Risk factors for acquisition of MSSA and MRCoNS infections in neonates hospitalized in the Neonatal Intensive Care Unit (NICU) of Uberlândia Federal University Hospital during the period of January-February/02.

\begin{tabular}{|c|c|c|c|c|c|c|}
\hline \multirow{2}{*}{$\frac{\text { Risk factor }}{\text { Weight }}$} & \multicolumn{2}{|c|}{$\begin{array}{l}\text { Cases } \\
\mathrm{N}=12\end{array}$} & \multicolumn{2}{|c|}{$\begin{array}{c}\text { Controls } \\
\mathrm{N}=24\end{array}$} & \multirow[t]{2}{*}{$\mathrm{OR}\left(\mathrm{CI}_{95 \%}\right)$} & \multirow[t]{2}{*}{$\mathrm{P}$} \\
\hline & $\mathrm{N}$ & $\%$ & $\mathrm{~N}$ & $\%$ & & \\
\hline$>1500 \mathrm{~g}$ & 5 & 41.7 & 14 & 58.3 & $1.96(0.39-10.13)$ & 0.55 \\
\hline$\leq 1500 \mathrm{~g}$ & 7 & 58.3 & 10 & 41.7 & & \\
\hline \multicolumn{7}{|l|}{ Sex } \\
\hline Feminine & 6 & 50.0 & 14 & 58.3 & $1.40(0.28-7.05)$ & 0.90 \\
\hline Masculine & 6 & 50.0 & 10 & 41.7 & & \\
\hline \multicolumn{7}{|l|}{ Age } \\
\hline$>7$ days & 3 & 33.3 & 18 & 75.0 & $9.00(1.47-63.34)$ & $0.01 *$ \\
\hline$\leq 7$ days & 9 & 66.7 & 6 & 25.0 & & \\
\hline \multicolumn{7}{|l|}{ Gestation (weeks) } \\
\hline $26-29$ & 2 & 16.7 & 6 & 25.0 & $1.67(0.23-14.74)$ & 0.69 \\
\hline $30-33$ & 2 & 16.7 & 8 & 33.3 & $2.50(0.36-21.29)$ & 0.43 \\
\hline $34-36$ & 8 & 66.7 & 10 & 41.7 & $0.36(0.06-1.86)$ & 0.28 \\
\hline \multicolumn{7}{|c|}{ Length of hospitalization } \\
\hline \multicolumn{7}{|l|}{ Apgar in the 5} \\
\hline $0-4$ & 1 & 8.3 & 5 & 20.8 & $2.89(0.26-74.40)$ & 0.63 \\
\hline $5-7$ & 4 & 33.3 & 10 & 41.7 & $1.43(0.27-7.77)$ & 0.72 \\
\hline 8-10 & 7 & 58.3 & 9 & 37.5 & $0.43(0.08-2.16)$ & 0.40 \\
\hline Incubator & 10 & 83.3 & 17 & 70.8 & $0.49(0.06-3.45)$ & 0.68 \\
\hline Antibiotic use & 11 & 91.7 & 18 & 75.0 & $0.27(0.01-2.95)$ & 0.38 \\
\hline Ampicillin & 11 & 91.7 & 18 & 75.0 & $0.27(0.01-2.95)$ & 0.38 \\
\hline Amicacin & 11 & 91.7 & 18 & 75.0 & $0.27(0.01-2.95)$ & 0.38 \\
\hline$>2$ antibiotics & 4 & 33.3 & 2 & 8.3 & $0.18(0.02-1.53)$ & 0.14 \\
\hline \multicolumn{7}{|l|}{ Use of } \\
\hline CVC & 10 & 83.3 & 9 & 37.5 & $0.12(0.01-0.81)$ & $0.02 *$ \\
\hline PVC & 11 & 91.7 & 20 & 83.3 & $0.45(0.02-5.47)$ & 0.64 \\
\hline
\end{tabular}

$* \mathrm{p} \leq 0.05 ; \mathrm{MSSA}=$ methicillin susceptible Staphylococcus aureus; MRCoNS = methicillin resistant coagulase-negative staphylococci; $\mathrm{OR}=$ odds ratio; $\mathrm{CI}_{95 \%}=95 \%$ confidence intervals $; \mathrm{CVC}=$ central vascular catheter; $\mathrm{PVC}=$ peripheral venous catheter 
D.V.D. de Brito et al.

Table 3. Risk factors for acquisition of MSSA and MRCoNS infections in neonates hospitalized in the Neonatal Intensive Care Unit (NICU) of Uberlândia Federal University Hospital during the period of August-September/02.

\begin{tabular}{|c|c|c|c|c|c|c|}
\hline \multirow{2}{*}{$\begin{array}{l}\text { Risk factor } \\
\text { Weight }\end{array}$} & \multicolumn{2}{|c|}{$\begin{array}{l}\text { Cases } \\
\mathrm{N}=8\end{array}$} & \multicolumn{2}{|c|}{$\begin{array}{c}\text { Controls } \\
\mathrm{N}=24\end{array}$} & \multirow[t]{2}{*}{$\mathrm{OR}\left(\mathrm{CI}_{95 \%}\right)$} & \multirow[t]{2}{*}{$\mathrm{P}$} \\
\hline & $\mathrm{N}$ & $\%$ & $\mathrm{~N}$ & $\%$ & & \\
\hline$\leq 1500 \mathrm{~g}$ & 6 & 75.0 & 9 & 37.5 & & \\
\hline \multicolumn{7}{|l|}{ Sex } \\
\hline Feminine & 3 & 37.5 & 12 & 50.0 & $0.60(0.09-3.94)$ & 0.69 \\
\hline \multicolumn{7}{|l|}{ Age } \\
\hline$>7$ days & 2 & 37.5 & 19 & 79.2 & $0.09(0.01-0.73)$ & $0.009 *$ \\
\hline$\leq 7$ days & 6 & 62.5 & 5 & 20.8 & & \\
\hline \multicolumn{7}{|l|}{ Gestation (weeks) } \\
\hline $26-29$ & 2 & 25.0 & 6 & 25.0 & $1.00(0.10-8.32)$ & 1.00 \\
\hline $30-33$ & 2 & 25.0 & 12 & 50.0 & $0.47(0.05-3.52)$ & 0.67 \\
\hline \multicolumn{7}{|l|}{ Apgar in the 5} \\
\hline $0-4$ & 2 & 25.0 & 4 & 33.3 & $0.67(0.07-5.20)$ & 1.00 \\
\hline $5-7$ & 2 & 37.5 & 6 & 33.3 & $1.20(0.17-8.29)$ & 1.00 \\
\hline $8-10$ & 2 & 37.5 & 6 & 33.3 & $1.20(0.17-8.29)$ & 1.00 \\
\hline Incubator & 7 & 87.5 & 16 & 66.6 & $1.00(0.0-18.98)$ & 1.00 \\
\hline \multicolumn{7}{|l|}{ Antibiotic use } \\
\hline Ampicillin & 8 & 100.0 & 20 & 83.3 & $0.00(0.00-9.28)$ & 0.53 \\
\hline Amicacin & 8 & 100.0 & 20 & 83.3 & $0.00(0.00-9.28)$ & 0.53 \\
\hline$>2$ antibiotics & 8 & 100.0 & 20 & 83.3 & $0.00(0.00-9.28)$ & 0.53 \\
\hline \multicolumn{7}{|l|}{ Use of } \\
\hline $\mathrm{CVC}$ & 6 & 75.0 & 6 & 25.0 & $0.11(0.01-1.05)$ & $0.03^{*}$ \\
\hline
\end{tabular}

$* \mathrm{p} \leq 0.05$; MSSA = methicillin susceptible Staphylococcus aureus; MRCoNS = methicillin resistant coagulase-negative staphylococci; OR= odds ratio; $\mathrm{CI}_{95 \%}=95 \%$ confidence intervals $; \mathrm{CVC}=$ central vascular catheter; $\mathrm{PVC}=$ peripheral venous catheter.

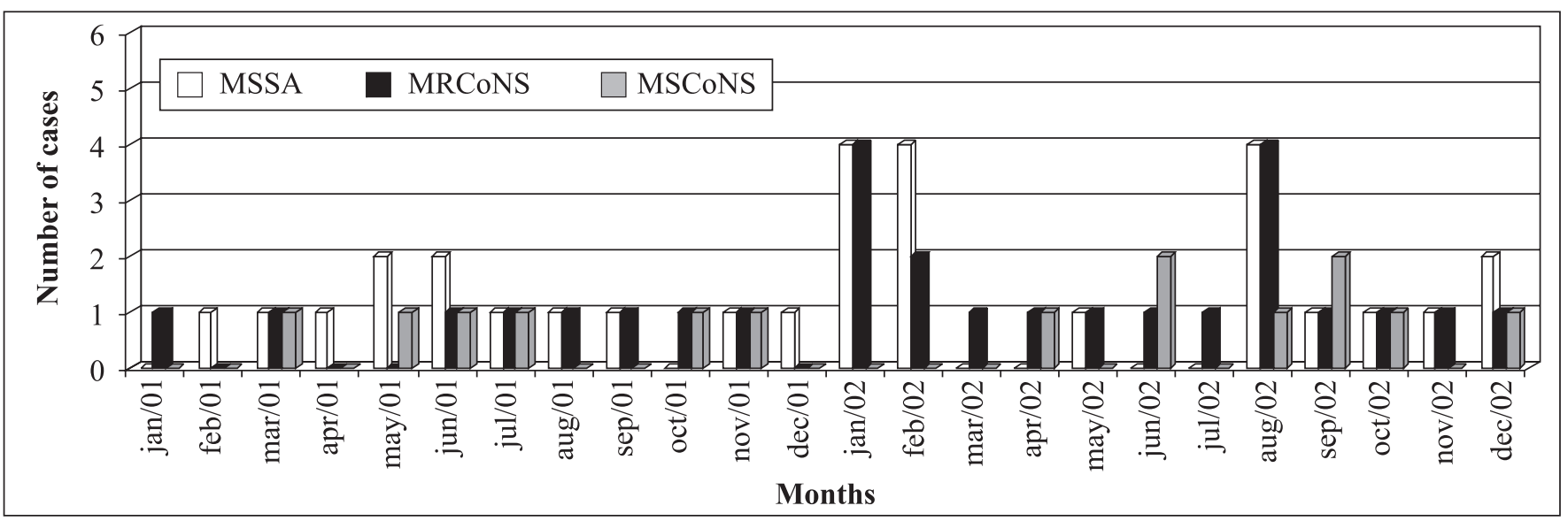

Figure 1. Incidence of MSSA and CoNS isolated from bloodstream in the NICU of Uberlândia Federal University Hospital from January/2001 to December/2002. 


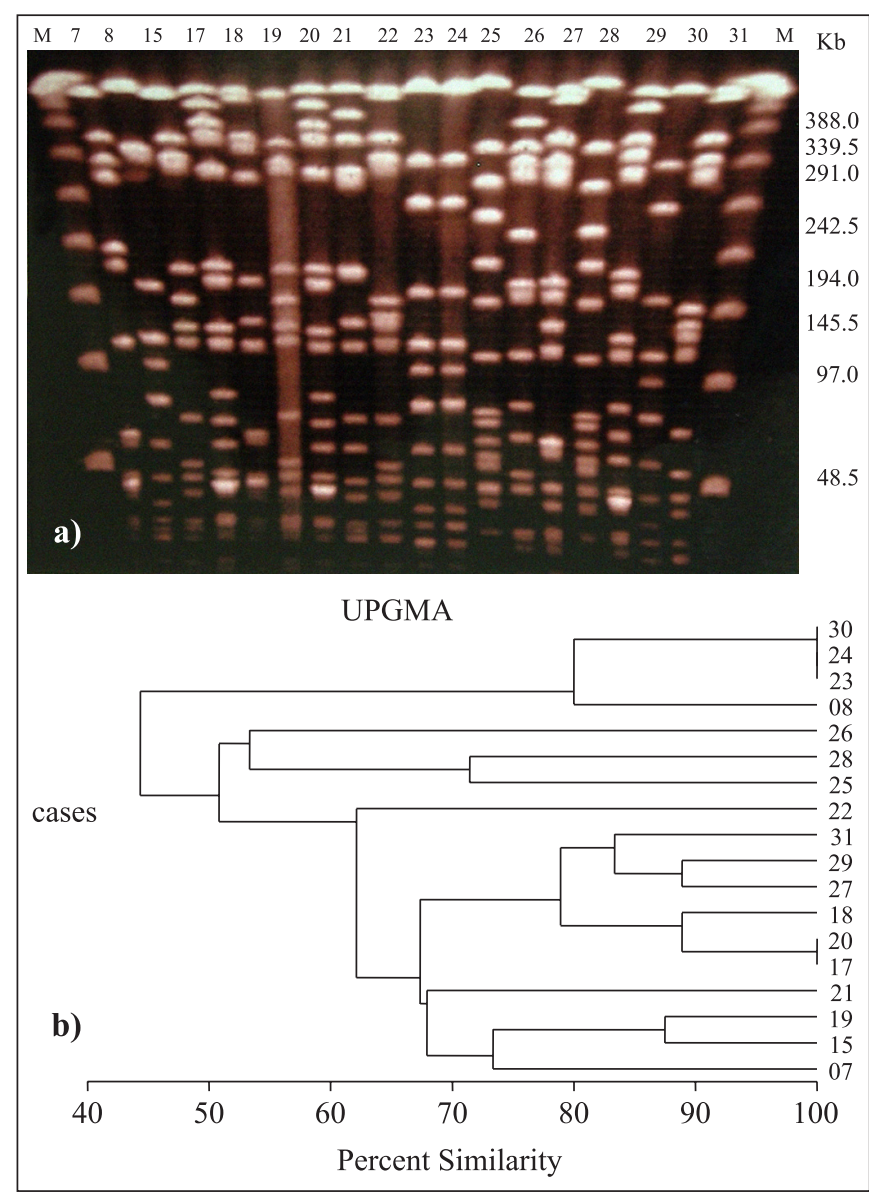

Figure 2. PFGE profiles of SmaI-digested genomic DNA of 18 Staphylococcus aureus strains. (a) Lanes M represent the concatamer of DNA lambda; lanes 7 to 19 contain the digested DNA of endemic period and lanes 20 to 31 contain the digested DNA of epidemic period. (b) Dendrogram resulting from the computer-assisted analysis of the PFGE profiles.

\section{DISCUSSION}

The infections in premature neonates are most frequent and habitually most serious, associated with high mortality (8). The prolonged period of internment of very low birth weight babies $(\mathrm{w}<1000 \mathrm{~g})$, in addition with immunological immaturity, exigency of mechanical ventilation and intravascular catheter, justify the major susceptibility to microorganisms and occurrence of outbreaks (19).

Two outbreaks were detected in the period of two years (2001-2002) at the Neonate Intensive Care Unit (NICU) of Uberlândia Federal University Hospital, being two of mixed etiology of MSSA and MRCoNS, defined through statistical analysis with incidence rates, in the epidemic periods significant $(\mathrm{p} \leq 0.05)$. The incidence rates of staphylococci by $S$. aureus and CoNS were respectively $3.77 \%$ and $5.16 \%$ in the investigated period.

While the proportion of epidemic infections all over the hospital is between $5 \%$ to $10 \%$ of nosocomial infection (15), in critic neonates they are more frequent (4). However, the outbreaks in NICU described in the literature were usually associated to one epidemic strain (22) and to one specific clone (26). There are evidences that the majority of outbreaks in other units had one polymicrobial or polyclonal etiology (9). In spite of the fact that the greater portion of infections was monoclonal, polyclonal infections are related and probably they are more frequent in developing countries because of a major chance of failure in control practices and prevention of nosocomial infections and the chronic lack of basic items necessary in the patient care (1).

The CoNS is one of the most important nosocomial pathogens especially in premature neonates (27), but usually without relation with outbreaks because of it's low virulence (10). On the other hand, S.aureus represents not only one of main agents of infection in these units but it's also associated in many times to epidemic (6). S. aureus and CoNS are considered the main cause of late sepsis in NICU (18), connected with neonates of low weight (3). In this series, sepsis (66.7\%) and conjunctivitis $(27.4 \%)$ were the episodes more observed in neonates.

According to reports of the country, $(2,13)$ a predominance of MRSA was verified in the cases of sepsis by $S$. aureus in neonates hospitalized on the contrary of the one(s) observed in our investigation, in which this phenotype was not detected. However, oxacillin resistant phenotype in CoNS isolates related to two outbreaks, represented $65.8 \%$ of infection episodes. The frequency of this resistance marker is more expressive in CoNS than in $S$. aureus, considering patients hospitalized in critical units $(5,10)$.

Our results showed the following risk factors associated to cases referring to two outbreaks: central vascular catheter (CVC) inserted using the phlebotomy technique, age $\leq 7$ days and hospitalization $\geq 7$ days. Nevertheless, none of them were independent risk factor by multivariate analysis. The insertion of catheter by dissection (phlebotomy) increases in at least six times the risk of infection when compared with the Peripherally Inserted Central Catheter (PICC) (20). The outbreaks were controlled in two opportunities by re-establishment of PICC due to constant necessity of central catheter.

The technique of PFGE is considered to present, one of the highest discriminatory power in study of nosocomial outbreaks caused by $S$. aureus and other microorganisms (28). In this study PFGE showed polyclonal spread of $S$. aureus during both, epidemic and endemic period. In conclusion, two outbreaks were identified of mixed etiology by MSSA and MRCoNS associated to the lack of an adequate material (central venous catheter) for neonates, related to invasive procedures. 


\section{ACKNOWLEDGEMENTS}

This work was supported by Fundação de Amparo à Pesquisa do Estado de Minas Gerais (FAPEMIG).

\section{RESUMO}

\section{Surtos associados a infecções sanguíneas por Staphylococcus aureus e Staphylococcus spp coagulase-negativa em neonatos prematuros em um hospital universitário do Brasil}

Staphylococcus aureus e Estafilococos coagulase-negativa (ECN) estão entre os patógenos hospitalares mais importantes em pacientes de unidades de terapia intensiva neonatal, principalmente em infecções da corrente sanguínea. O principal objetivo deste estudo foi determinar a ocorrência de infecções hospitalares por estes microrganismos usando dois sistemas de vigilância (laboratorial e "National Nosocomial Infection Surveillance" - NNIS) e determinar os fatores de risco mais importantes durante o período de dois anos (2001-2002). Dois surtos por ambos S. aureus suscetível a meticilina (1.5\%) e ECN resistente à meticilina (1.0\%) foram observados, de janeiro a fevereiro/02 e agosto a setembro/02. Taxas de incidência endêmica de $3.77 \%$ e $5.16 \%$ para S.aureus e ECN foram detectadas respectivamente. Fatores de risco incluíram idade $\leq 7$ dias, hospitalização $\geq 7$ dias e utilização de cateter vascular central (CVC) de polietileno através de dissecação de veia (flebotomia), mas, nenhum desses fatores independentes foram confirmados pela análise multivariada. Por outro lado, ECN resistente à oxacilina prevaleceu $(66.0 \%)$ nos episódios epidêmicos. Análise molecular através de gel de eletroforese em campo pulsátil mostrou a natureza policlonal das amostras de S. aureus. Em conclusão, nós identificamos dois surtos de etiologia mista por $S$. aureus suscetível à meticilina e ECN resistente à meticilina associados à falta de material adequado (cateter vascular central) para neonatos, relacionados a procedimento invasivo. Os dois surtos foram controlados com a substituição de CVC de polietileno pelo cateter central de inserção periférica.

Palavras-chave: Polimicrobiano, policlonal, surtos, neonatos, estafilococos

\section{REFERENCES}

1. Aiello, A.E.; Cimiotti, J.; Della-Latta, P.; Larson, E.L. A comparison of the bacteria found on the hands of 'homemakers' and neonatal intensive care unit. J. Hosp. Infect., 54, 310-315, 2003.

2. Andersen, B.M.; Lindemann, R.; Bergh, K.; Nesheim, B.I.; Syversen, G.; Solheim, N.; Laugerud, F. Spread of methicillin-resistant Staphylococcus aureus in a neonatal intensive unit associated with understaffing, overcrowding and mixing of patients. J. Hosp. Infect., $50,18-24,2002$.
3. Beck-Sague, C.M.; Azimi, P.; Fonseca, S.N.; Baltimore, R.S.; Powell, D.A.; Bland, L.A.; Arduino, M.J.; McAllister, S.K.; Huberman, R.S.; Sinkowitz, R.L. Bloodstream infections in neonatal intensive care unit patients: results of a multicenter study. Pediatr. Infect. Dis. J., 13, 1110-1116, 1994.

4. Brito, D.V.D.; Matos, C.; Abdallah, V.; Diogo Filho, A.; Gontijo Filho, P.P. An outbreak of nosocomial infection caused by ESBLs producing Serratia marcescens in a Brazilian Neonatal Unit. Braz. J. Infect. Dis., 3, 149-155, 1999.

5. Chambers, H.F. Methicillin resistance in staphylococci: molecular and biochemical basis and clinical implications. Clin. Microbiol. Rev., 10, 781-791, 1997.

6. Corbella, X.; Dominguez, M.A.; Pujol, M.; Ayats, J.; Sendra, M.; Pallares, R.; Ariza, J.; Gudiol, F. Staphylococcus aureus nasal carriage as a marker for subsequent staphylococcal infections in intensive care unit patients. Eur. J. Clin. Microbiol. Infect. Dis., 16, 351-357, 1997.

7. Hakim, A.; Deplano, A.; Maes, N.; Kentos, A.; Rossi, C.; Struelens, M.J. Polyclonal coagulase-negative staphylococcal catheter-related bacteremia documented by molecular identification and typing. Clin. Microbiol. Infect., 5, 224-227, 1999.

8. Harris, J.S. Pediatrics nosocomial infections: children are not little adults. Infect. Control Hosp. Epidemiol., 18, 739-742, 1997.

9. Khatib, R.; Sharma, M.; Naqvi, S.A.H.; Riederer, K.; Almoujahed, M.O.; Fakih, M.G. Molecular analysis of Staphylococcus aureus blood isolates shows lack of polyclonal bacteremia. J. Clin. Microbiol., 41, 1717-1719, 2001.

10. Krediet, T.G.; Jones, M.E.; Janssenn, K.; Gerards, L.J.; Fleer, A. Prevalence of molecular types and mecA gene carriage of coagulasenegative staphylococci in a Neonatal Intensive Care Unit: relation to nosocomial septicaemia. J. Clin. Microbiol., 39, 3376-3378, 2001.

11. Lally, R.T.; Lanz, E.; Schrock, C.G.; Minnesota, R. Rapid control of an outbreak of Staphylococcus aureus on a Neonatal Intensive Care department using standard infection control practices and nasal mupirocin. Am. J. Infect. Control, 32, 44-47, 2004.

12. Loureiro, M.M.; Moraes, B.A.; Quadra, M.R.R.; Pinheiro, G.S.; Suffys, P.N.; Asensi, M.D. Molecular epidemiology of methicillin resistant Staphylococcus aureus isolated from newborns in a hospital in Rio de Janeiro, Brazil. Mem. Inst. Oswaldo Cruz, 95, 777-782, 2000.

13. Loureiro, M.M.; Moraes, B.A.; Quadra, M.R.R.; Pinheiro, G.S.; Asensi, M.D. Study of multi-drug resistant microorganisms isolated from blood cultures of hospitalized newborns in Rio de Janeiro city, Brazil. Braz. J. Microbiol., 33, 73-78, 2002.

14. Magalhães, M.; Doherty, C.; Govan, J.R.W.; Vandamme, P. Polyclonal outbreak of Burkholderia cepacia complex bacteremia in haemodialysis patients. J. Hosp. Infect., 54, 120-123, 2003.

15. McGowan, J.E.; Metchock, B. Infection control epidemiology and clinical microbiology. In: Murray, P.R.; Baron, E.J.; Pfaller, M.A.; Tenover, F.C.; Yolken, R.H. (eds) Manual of Clinical Microbiology, Washington, D.C. 1995 , p. 182-189.

16. National Committee for Clinical Laboratory Standards. Performance Standards Antimicrobial Disk Susceptibility tests. NCCLS, Villanova, PA, 2004.

17. National Committee for Clinical Laboratory Standards. Methods for dilution antimicrobial susceptibility tests for bacteria that grow aerobically. NCCLS, Villanova, PA, 2004.

18. Patrick, C.C.; Kaplan, S.L.; Baker, C.J.; Parisi, J.T.; Mason, E.O. Persistent bacteremia due to coagulase-negative staphylococci in low birth weight neonates. Pediatr., 84, 977-985, 1989.

19. Pawa, A.K.; Ramji, S.; Prakash, K.; Thirupuram, S. Neonatal nosocomial infection: profile and risk factors. Ind. Pediatr., 34, 297-302, 1997.

20. Raad, I.; Davis, S.; Becker, M. Low infection rate and long durability of nontunneled silastic catheters. A safe cost-effective alternative 
for long-term venous access. Arch. Intern. Med., 153, 1791-1796, 1993.

21. Rijnders, B.J.A; Wijngaerden E.V.; Eldere J.V.; Peetermans W.E. Polyclonal Staphylococcus epidermidis catheter-related infections. Clin. Microbiol. Infect., 7, 388-390, 2001.

22. Shiojima, T.; Ohki, Y.; Morikawa, A.; Okubo, T.; Iyobe S. Immediate control of a methicillin-resistant Staphylococcus-aureus outbreak in a Neonatal Intensive Care Unit. J. Infect. Chemother., 9, 243247, 2003.

23. Spanu, T.; Sanguinetti, M.; D’Inzeo, T.; Ciccaglione, D.; Romano, L.; Leone, F.; Mazzella, P.; Fadda, G. Identification of methicillinresistant isolates of Staphylococcus aureus and coagulase-negative Staphylococcus responsible for bloodstream infections with Phoenix TM system. Diagn. Microbiol. Infect. Dis., 48, 221-227, 2004.

24. Tenover, F.C.; Arbeit, R.; Goering, R.V.; Mickelsen, P.A.; Murray, B.E.; Persing, D.H.; Swaminathan, B. Interpreting chromosomal DNA restriction patterns produced by pulsed field gel electrophoresis criteria for bacterial strain typing. J. Clin. Microbiol., 33, 22332239,1995
25. VanEldre, J.; Peetermans, W.E.; Struelens, M.J.; Deplano, A.; Bobbaers, H. Polyclonal staphylococcal endocarditis caused by genetic variability. Clin. Infect. Dis., 31, 24-30, 2000.

26. Vermont, C.L.; Hartwig, N.G.; Fleer, A.; Man, P.; Verbrugh, H.; Anker, J.; Groot, R.; Belkum, A. Persistence of clones of coagulase-negative Staphylococcus among premature neonates in Neonatal Intensive Care Units: two-center study of bacterial genotyping and patient risk factor. J. Clin. Microbiol., 36, 2485-2490, 1998.

27. Villari, P.; Sarnataro, C.; Iacuzio, L. Molecular epidemiology of Staphylococcus epidermidis in a Neonatal Intensive Care Unit over a three year period. J. Clin. Microbiol., 38, 1740-1746, 2000.

28. Weller, T.M.A. Methicillin-resistant Staphylococcus aureus typing methods: which should be the international standard? J. Hosp. Infect., 44, 160-172, 2000

29. Wendt, C.; Messar, S.A.; Hollis, R.J.; Pfaller, M.A.; Herwaldt, L.A Epidemiology of polyclonal Gram-negative bacteremia. Diagn. Microbiol. Infect. Dis., 32, 9-13, 1998.

30. Worsley, M.A. Nursing priorites and the contribution of the Internation Federation of Infection Control. J. Hosp. Infect., 18, 392-396, 1991. 